\title{
KANTELEPELIMANNIT ARVI, AARNE JA ALFRED
}

\section{Tikkusoittotradition soiva tyylintutkimus}

Tämä artikkeli käsittelee suomalaisen kanteleperinteen yhtä lajia, tikkusoittoa. Olen paneutunut aiheeseen osana taiteellista tohtorintutkintoani Taideyliopiston Sibelius-Akatemiassa. Koko tutkinto koostuu viidestä konsertista sekä tutkielmasta, jonka yhden osuuden tämä artikkeli muodostaa. Perehdyin arkistoissa olevaan tikkusoittoon työstäessäni toista jatkotutkintokonserttiani. Sen jälkeen olen jatkanut syventymistä tikkusoittoperinteeseen, sillä kyseistä arkistomateriaalia on tutkittu tähän saakka hyvin vähän, vaikka perinteisten tikkusoittotyylien kirjo on aineiston perusteella laaja. Näkökulmani aiheeseen on musiikkianalyyttinen, mutta arkistoaineiston tutkiminen on tapahtunut ensisijaisesti soittamalla havainnoiden.

Tikkusoitto perustuu sulkutekniikkaan, jossa toisen käden sormet sammuttavat eli "sulkevat" osan kanteleen kielistä. Avoimiksi jäävät kielet vetäistään soimaan puutikulla tai kovalla nahanpalalla, ja vasemman käden sammuttavia sormia käytetään myös kielten näppäilemiseen. Elävä tikkusoittoperinne oli hiipunut voimakkaasti 1980-luvulle tultaessa, mutta sen jälkeen soittotapaa pidettiin yllä muutamien henkilöiden toimesta muun muassa Kansanmusiikki-instituutin järjestämillä kursseilla sekä Sibelius-Akatemian kansanmusiikin osastolla (nykyisin Taideyliopiston Sibelius-Akatemian kansanmusiikin aineryhmä). Jälkimmäisessä tikkusoittoa piti esillä kansanmusiikin lehtori Sinikka Järvinen (nyk. Kontio), jo- 
ka kehitti 1990-luvun alussa oman pedagogisen metodinsa tikkusoittotraditiota edustaneen mestaripelimanni Arvi Pokelan (1914-1984) soittotyylin opettamiseen (Kontio h2018). Kontion oppilaana ollessani innostuin itsekin tikkusoitosta ja siitä saakka olen pyrkinyt edesauttamaan sen näkyvyyttä niin opettajana kuin muusikkonakin. Nykyisin tikkusoittajia on enemmän kuin vuosikymmeniin.

Aiheen parissa on toistaiseksi tehty tutkimusta niukasti, eikä yleinen käsitteistökään ole vielä vakiintunutta. Kansanmusiikin tutkija Hannu Saha hyödyntää väitöskirjassaan Kansanmusiikin tyyli ja muuntelu sanaa tikkusoitto kuvaamaan ison kanteleen soittamista sulkutekniikalla tikkua apuvälineenä käyttäen (Saha 1996: 176). Olen päätynyt käyttämään tikkusoitto-termiä, sillä se ilmentää kyseistä soittotapaa mielestäni parhaiten. Kansanperinteen tutkija ja tallentaja Erkki Ala-Könni (1986: 31-38) avasi artikkelissaan Saarijärven kantele soitinrakennuksen ja tikulla soittamisen kukoistusta Saarijärvellä 190o-luvun alkuvuosikymmeninä. Tästä johtuen soittotapaa on myöhemmin kutsuttu myös Saarijärven tyyliksi ja tikulla soitettavia ja rakenteeltaan tietyn mallisia kanteleita Saarijärven kanteleiksi. Soitintutkija Kari Dahlblom (2011: 50-52) puolestaan halusi nimityksen kattavan koko keskisuomalaisen tradition ja käytti termiä Keski-Suomen maakuntakantele. Itse tarkastelen tikkusoittoa laajemmin kuin saarijärveläisenä tai keskisuomalaisena ilmiönä, joten olen halunnut löytää nimityksen, joka ei ole maantieteellinen.

Artikkelin kysymyksenasettelu kytkeytyy sekä tikkusoiton perinnetyyleihin että niiden tutkimiseen soittamalla arkistomateriaaliin pohjautuen. Tarkastelen kolmen tikkusoittoperinnettä edustavan pelimannin henkilökohtaista tyyliä. Millaisina soittotyylit näyttäytyvät, kun niitä lähestyy näiltä kaikilta soittajilta tallennetun Hienohelma-kappaleen versioita vertaillen ja analysoiden? Toisaalta syvennyn soittaen tehtävään tyylintutkimukseen. Selvitän, miten tyylintutkimuksen prosessi etenee, kun muusikko tutkii perinnetyylejä soittonsa avulla arkistomateriaaliin perustuen. Millaisia haasteita hän tässä työssä kohtaa? Lopuksi valotan, miten tämän päivän (tikku)soittaja hyötyy (tikkusoitto)perinteen eri tyylien ymmärtämisestä.

Soittamalla havainnoinnin olen tehnyt Saarijärven kanteleella, jonka on rakentanut Kari Kauhanen vuonna 2002. Saarijärven kanteleita valmisti Saarijärvellä 1800- ja 1900-lukujen vaihteessa useampi soitinrakentaja (Ala-Könni 1986: 32-37). Niissä oli diatoninen asteikko ja toisinaan myös kolme bassokieltä, jotka oli sijoitettu suuremman välimatkan päähän toisistaan, jotta tikulla osuisi kie- 
leen paremmin. Bassokielet oli viritetty duuriasteikon kolmen perussointuasteen (I, IV, v) mukaan. (Nieminen h2018.) Kauhanen rakensi oman kanteleeni soitinrakentaja Rauno Niemisen vuonna 1982 suunnitteleman piirustuksen pohjalta. Piirustus perustuu saarijärveläisen Jooseppi Pohjolan (1873-1945) rakentamiin soittimiin, joissa oli viisitoista diskanttikieltä ja kolme bassokieltä. Piirustuksessa soittimen muoto on sama kuin Pohjolalla, mutta muutoksia on tehty muun muassa kannen rakenteeseen ja kielten mitoitukseen (Nieminen h2018). Usein tikkusoitto liitetään juuri Saarijärven kanteleisiin, mutta soittotekniikkaa on mahdollista toteuttaa millä tahansa kanteleella.
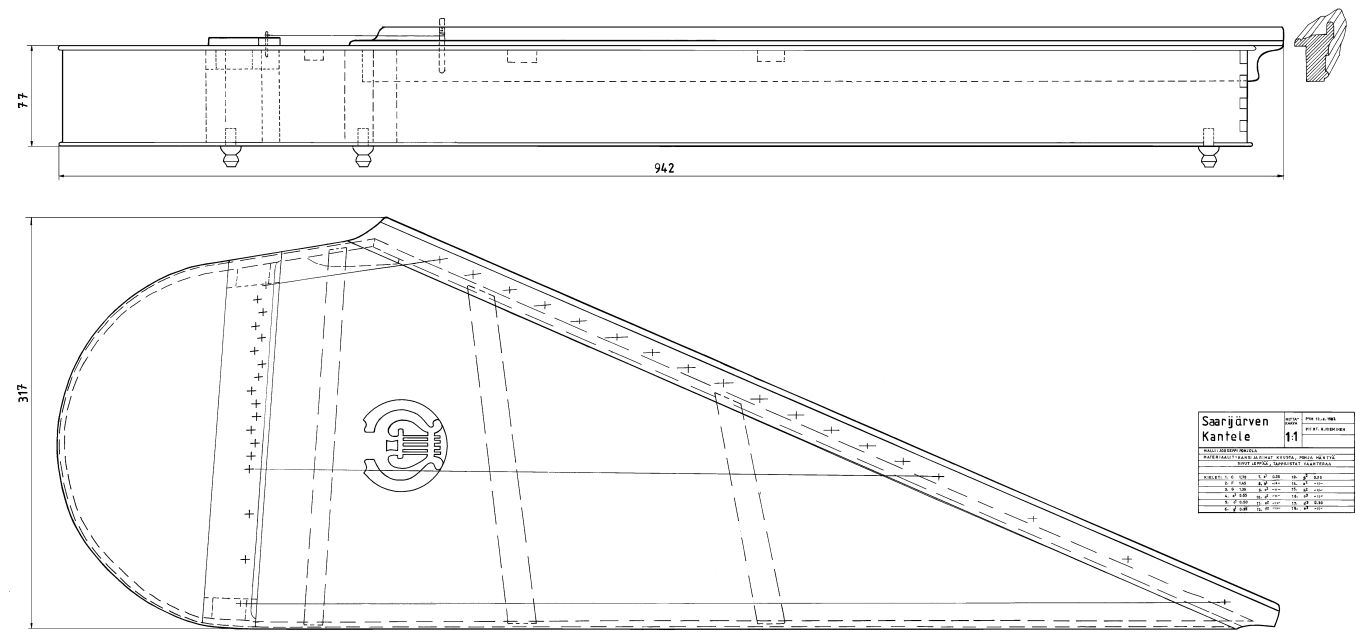

Kuva 1. Saarijärven kanteleen piirustus. Rauno Nieminen 1982

\section{Tutkimusmenetelmät ja aineisto}

Artikkelin taustatyössä olen tutkinut ja opiskellut perinnettä arkistotallenteilta soittaen sekä analysoiden, esittänyt perinnetyylejä tutkintokonsertissa ja pohtinut syvällisesti suhdettani traditioon. Tällaisessa tutkimusasetelmassa muusikko havittelee tietoa, jota ei voi saavuttaa muulla tavoin kuin soittamalla. Kansan- 
musiikin tyylipiirteitä tutkinut Saha (1996: 75) kirjoittaa, että "tyyli voidaan tunnistaa tuotteista (soitosta, sävelmästä, musiikista) mutta selittää vain sen tekoprosesseista, musiikista" käsin. Tikkusoittoon syvällisesti perehtynyt muusikko kykeneekin oman soittonsa avulla selvittämään, miten arkistonauhalla musisoiva pelimanni on toteuttanut soittamansa musiikin. Soittamalla havainnoiminen on tämän tutkimuksen tärkein menetelmä, ja sitä, kuinka se käytännössä tapahtuu, avaan tuonnempana omassa luvussaan.

Kansanmusiikin emeritusprofessori Heikki Laitisen tunnetuksi tekemä tutkimuksen lähestymistapa musisoiva tutkija, tutkiva muusikko on työssäni olennainen. Tällöin vaihdetaan tietoisesti näkökulmaa muusikosta tutkijaksi ja toisinpäin. Laitisen ajattelu pohjautuu sekä 1970-luvun alussa Euroopassa syntyneeseen niin sanottuun tanssivaan ja musisoivaan tutkimukseen että amerikkalaiseen 1960-luvulla esiin nousseeseen etnomusikologiseen koulukuntaan (ks. esim. Lomax 1968; Nettl 1964). Laitinen oli vaikuttunut etenkin unkarilaisesta tanssitupaliikkeestä, jonka piirissä eurooppalainen tanssiva ja musisoiva tutkimus hänen mukaansa syntyi. Silloisen sosialistisen ammattilaisfolklorismin rinnalle nousi toisenlainen alkuperäiseen traditioon perustuva esittämistapa, johon haettiin oppia kylistä ja arkistolähteistä. (Laitinen 2003b: 336.)

Omassa tutkimuksessani muusikko ja tutkija ovat läsnä koko ajan. Tutkiva muusikko - musisoiva tutkija hahmottaa perinnetyylejä soittamansa musiikin ja tunteen kautta otteen pysyessä silti analyyttisenä. Muusikkouden avulla voi löytää sellaista tietoa, joka täydentää merkittävällä tavalla muuta tutkimusta, ja myös tunteella on oma merkityksensä oivalluksen ja tiedon lähteenä (Laitinen 2003b: 336). Filosofi Juha Varto (2017: 35) puolestaan kirjoittaa taiteellista tutkimusta käsittelevässä kirjassaan, että taiteellisen tutkimuksen tekijässä "aistiminen, ajatteleminen ja tekeminen toimivat yhdessä, koska tekijä luottaa taitoonsa ja siksi etenee koko rintamalla". Kokemukseni mukaan toiminta musisoivana tutkijana ja tutkivana muusikkona ilmentää Varton ajatuksen mukaista kokonaisvaltaista tekijyyttä. Näenkin Laitisen lähestymistavan yhtenä taiteellisen tutkimuksen muotona, joka soveltuu erityisesti perinteen parissa työskentelyyn.

Hyödynnän myös Laitisen (2003b: 333) kehittämää kuvitellut kenttäretket -tutkimusmenetelmää. Se on ollut edellytys arkistoihin tallennettujen soitteiden kontekstin ja olemuksen ymmärtämiselle: useimmista soittajista on olemassa hyvin vähän tietoa, enkä toistaiseksi ole onnistunut löytämään aikalaiskuvauksia 
tikkusoitosta. Moniin kysymyksiin ei ole olemassa vastauksia. Tällöin on mahdollista käyttää apuna omaa mielikuvitusta ja lähteä kuvitelluille kenttäretkille vaikkapa tansseihin, iltamiin tai eri soittajien luo. Tällaisilla retkillä voi soittotilanteiden lisäksi rekonstruoida mielessään myös ympäristöä, jossa tutkittava perinne oli arkipäivää. Retkiin valmistaudutaan hyvin, sillä kaikki mahdollinen ennakkotieto tutkittavasta aiheesta tulee olla hallussa. Mielikuvitusretket sekä niin ikään Laitisen (2003b: 314) mainitsemat kuvitteelliset vuoropuhelut ovat kehittäneet ymmärrystäni tikkusoittotraditiosta ja tuoneet henkilökohtaisemmaksi osin kaukaiseltakin tuntunutta perinnettä.

Artikkelin tutkimusaineisto koostuu arkistotallenteista, jotka ovat peräisin neljästä eri arkistosta: Kansanmusiikki-instituutista Kaustiselta, Saarijärven museosta, Tampereen yliopiston Kansanperinteen arkistosta ja The Library of Congress -kirjaston arkistosta (Washington DC, Yhdysvallat) (ks. Taulukko 1). Tähän aineistoon kuuluvat kaikki tähän mennessä tiedossani olevat tallenteet, joilla voi kuulla tikulla soitettuja melodioita. Toistaiseksi olen löytänyt kymmenen melodiasoittajaa ja lisäksi joitakin esimerkkejä tikkusoitosta pelimannimusiikin säestyksessä. On mahdollista, että melodiasoittoa sisältäviä äänitteitä löytyy tulevaisuudessa arkistojen kätköistä vielä lisääkin, mutta traditio oli käynyt varsin harvinaiseksi jo siinä vaiheessa, kun sitä alettiin aktiivisesti kerätä. Kymmenen soittajan joukosta olen valinnut tässä artikkelissa tarkasteltavaksi kolmen pelimannin soittotyylit, jotka keskinäisen moninaisuutensa vuoksi muodostavat kattavan otoksen tikkusoiton arkistomateriaalista.

\section{Tikkusoiton tekniikka}

Soittamisen osalta tikkusoiton tutkimus on painottunut yhteen henkilöön, mestaripelimanni Arvi Pokelaan. Hänen tyyliään tutkivat 1990-luvun alkuvuosina yhdessä Sinikka Kontio ja Kurt Lindblad, joka oli Kontion kanteleoppilaana Sibelius-Akatemiassa (Kontio h2018). Kontion Resu-Rankan polkasta tekemä transkriptio julkaistiin Pokelan levynkannessa (1991) sekä Lindbladin Pokelasta kirjoittamassa lyhyessä artikkelissa (Lindblad 1991: 149-152). Ensimmäisenä tikkusoiton nosti esiin Erkki Ala-Könni alun perin vuonna 1963 ilmestyneessä artikkelissaan "Saarijärven kantele". Hän kuvailee sitä näin: 
Kanteleen käsittely oli sointuihin pyrkivää "sulkusoittoa" sikäli, että melkoinen osa sävelistä saatiin lyömällä nahkatupulla, tikulla tai oikean käden etusormella niitä vapaita kieliä, jotka jäivät vasemman käden sulkevien sormien $(2,3)$ väliin ja vierelle. (Ala-Könni 1986 [1963]: 37.)

Kurt Lindblad puolestaan kirjoittaa seuraavasti:

Sulkutyylissä toisen käden sulkevien sormien väliin jääviä kieliä lyödään puutikulla tai sormella. Melodiasävelen lisäksi soi lähes aina yksi tai kaksi muuta säveltä, mikä antaa soitolle soinnukkaan sävyn. Melodiasäveltä on usein vaikea erottaa sävelkudoksesta. (Lindblad 1991: 150.)

Ala-Könni ja Lindblad nostavat esiin soittotavan kannalta merkittävän seikan: soittoa luonnehditaan sointuihin pyrkiväksi tai soinnukkaan sävyiseksi. Huomio on sulkutekniikan näkökulmasta olennainen, sillä tätä tekniikkaa käytettäessä soitto pohjautuu soinnuille. Sulkusoitosta puhuttaessa sammuttavien sormien sijaintia kielillä nimitetään sulkuotteiksi, jotka käytännössä ovat myös sointuotteita. Sulkusoitto mahdollistaa melodian ja sointujen tuottamisen samanaikaisesti. Soittaja voi tikulla soittavan käden liikettä hallitsemalla päättää, haluaako hän korostaa melodiaa vai ottaa mukaan myös melodian ulkopuolisia soinnun ääniä.

Näppäilyn ja tikun vuorottelu sekä sointujen tuoma moniäänisyys saavat aikaan sävelkudoksen, jota kanteleesta paljon kirjoittanut filosofian tohtori AnnaLiisa Tenhunen (2010: 254) kuvaa heliseväksi sekä rytmiltään ja säveliltään koko ajan vaihtelevaksi. Tenhusen luonnehdinta on osuva: sulkusoiton kuulokuva eroaa varsin paljon kanteleen näppäilysoitosta.

Arkistojen tikkusoitteita kuunnellessa huomio kiinnittyy usein ensimmäisenä sointujen ja melodian väliseen suhteeseen. Sointusatsin muhkeus, eli melodian lisäksi kuuluvien äänien määrä, on yksi tärkeä tekijä siinä, millainen käsitys kunkin soittajan tyylistä kuulijalle muodostuu. Lindbladin (1991: 150) mukaan melodiasävelen lisäksi lähes aina soi muitakin säveliä, ja tällöin melodiaa voi olla vaikea erottaa. Arkistotallenteita kuunnellessani olen kuitenkin huomannut, että jotkut pelimannit soittivat melodiat tarkasti, jopa lähes yksiäänisesti.

Sekä Ala-Könni että Dahlblom (2011: 34) kuvaavat soiton tapahtuneen tikulla, nahanpalalla tai oikean käden etusormella. Kaikki arkistotallenteilla kuulemani 
tämän soittotavan edustajat käyttivät tikkua. Sahan (2006: 412) mukaan "oikean käden etusormella, plektralla tai tulitikulla vetäistään muita kieliä ja aika ajoin bassoja soimaan". Ala-Könnin sekä Lindbladin kirjoituksissa sävelet saadaan ilmoille lyömällä kieliä, Dahlblom puhuu sulkevien sormien väliin jäävien kielten soittamisesta. Todennäköisesti soittajat ovat käyttäneet tikkua kukin omalla tavallaan eikä sanavalintoja ole välttämättä pohdittu kovin tarkasti tikkusoitosta kirjoitettaessa.

\section{Tikkusoitto arkistoissa}

Tikkusoittoa alettiin Suomessa taltioida arkistoihin vasta 1950-luvulta eteenpäin. Tällöin soittotapa oli jo harvinaistunut, sillä kansanmusiikki eli hiljaiseloa sotien jälkeisistä vuosista 196o-luvun lopulle saakka: uuden nuoriso- ja populaarimusiikin suosion kasvun seurauksena kansanmusiikille ei ollut aiemman kaltaista tilaa modernissa maailmassa. Kansanmusiikin uusi nousu alkoi 196o-luvun lopulta lähtien, minkä seurauksena moni jo soittamisen kertaalleen jättänyt pelimanni, Arvi Pokela mukaan lukien, aloitti sen uudestaan. (Asplund 2006: 507.)

Melodialähtöistä tikkusoittoa sisältävillä arkistonauhoilla musisoi kymmenen pelimannia. He ovat syntyneet Keski-Suomessa (6 soittajaa), Etelä-Pohjanmaalla (2 soittajaa), Hämeessä (1 soittaja) ja Savossa (1 soittaja). Taltioimisen painottuminen niin vahvasti juuri Keski-Suomeen lienee paljolti seurausta siitä, että Ala-Könni oli erittäin tietoinen juuri Keski-Suomen perinteestä ja keskitti tallennustyötään sille alueelle. Arvi Pokelaa lukuun ottamatta kultakin soittajalta on taltioitu ainoastaan kahdesta neljään kappaletta. 


\begin{tabular}{|c|c|c|c|}
\hline Soittaja & Syntymäpaikka & Tallentaja & Arkisto ja arkistointitunnus \\
\hline Alfred Backman (1885-1973) & Karstula & Erkki Ala-Könni 1954 & $\begin{array}{l}\text { Tampereen yliopisto, } \\
\text { Kansanperinteen arkisto } \\
\text { Kper A-K } 0054\end{array}$ \\
\hline Kalle Hakasalo (1881-1974) & Saarijärvi & Erkki Ala-Könni 1963 & $\begin{array}{l}\text { Tampereen yliopisto, } \\
\text { Kansanperinteen arkisto } \\
\text { Kper A-K } 0781\end{array}$ \\
\hline Salomo Korhonen (1903-1971) & Rautalampi & Erkki Ala-Könni 1968 & $\begin{array}{l}\text { Tampereen yliopisto, } \\
\text { Kansanperinteen arkisto } \\
\text { Kper A-K } 1418\end{array}$ \\
\hline Eino Manninen (1903-1981) & Saarijärvi & Arvi Pokela 1979 & $\begin{array}{l}\text { Saarijärven museo, } \\
\text { kasettinauha 122:32 }\end{array}$ \\
\hline Veikko Manninen (1904-2009) & Saarijärvi & Arvi Pokela 1979 & $\begin{array}{l}\text { Saarijärven museo, } \\
\text { kasettinauha 91:10 }\end{array}$ \\
\hline Aarne Moisio (1912-1988) & Vilppula & Erkki Ala-Könni 1968 & $\begin{array}{l}\text { Tampereen yliopisto, } \\
\text { Kansanperinteen arkisto } \\
\text { Kper A-K } 4510\end{array}$ \\
\hline Matti Perala (1885-1983) & Alavus & Sidney Robertson 1937 & $\begin{array}{l}\text { The Library of Congress, } \\
\text { Archive of Folk Culture, } \\
\text { Washington D. C. }\end{array}$ \\
\hline Arvi Pokela (1914-1984) & Saarijärvi & Useita tallentajia 1979-1984 & $\begin{array}{l}\text { Tallennekokoelma sijaitsee } \\
\text { Kansanmusiikki-instituutissa }\end{array}$ \\
\hline Albin Saari (1900-1962) & Vaasa & Ei tiedossa & $\begin{array}{l}\text { Kansanmusiikki-instituutti } \\
\text { KIÄ } 1116\end{array}$ \\
\hline Liinus Simpsiö (1885-1957) & Keuruu & Erkki Ala-Könni 1954 & $\begin{array}{l}\text { Tampereen yliopisto, } \\
\text { Kansanperinteen arkisto } \\
\text { Kper A-K } 00046\end{array}$ \\
\hline
\end{tabular}

Taulukko 1: Aineistoon kuuluvat soittajat ja arkistonauhat

Amerikansuomalainen Joyce Hakala on tehnyt tutkimusta 1900-luvun alussa Amerikkaan lähteneiden siirtolaisten kanteleensoitosta. Heidän joukossaan tikkusoittajia oli kuusi, joista yhden, Matti Peralan (Frans Matias Perälä), soittoa taltioitiin arkistoon vuonna 1937 (AFS 3274-3275; 3298B). Soittajista kolme oli lähtöisin Keski-Suomesta (Karstula ja Saarijärvi), kaksi Etelä-Pohjanmaalta (Alavus ja Ylihärmä) sekä yksi Varsinais-Suomesta (Alastaro). (Hakala 1997: 180-198.) Amerikansuomalaisten soittajien syntymäpaikat kertovat vahvasti siitä, että tikkusoitto on ollut 190o-luvun alussa yleinen soittotapa myös muualla kuin KeskiSuomessa.

Hakalan tutkimien siirtolaissoittajien ja suomalaisilla arkistonauhoilla musisoivien soittajien kotipaikkakuntien perusteella voi päätellä, että 190o-luvun alusta 1980-luvulle ulottuvana ajanjaksona tikkusoittoa on esiintynyt ainakin Hämeessä, Keski-Suomessa, Etelä-Pohjanmaalla ja Pohjois-Savossa. Kantelepelimanni Salomo Korhosen kotipaikka, Pohjois-Savossa sijaitseva Vesanto, on 
maantieteellisesti hyvin lähellä Keski-Suomea, eikä muista soittajista Savossa ole toistaiseksi tietoa. Näiden alueiden lisäksi tikkusoittoa on ollut ainakin KeskiPohjanmaalla, jossa soittotapa ilmeisesti alkoi hiipua jo 180o-luvulla (Saha 1996: 77). Tuolloin yleistyi lautakanteleen soittaminen eroasentoisesti, jolloin toisen käden sormilla näppäillään melodiakulut ja toisella säestyskuviot. Pohjois-Pohjanmaalla Haapavedellä puolestaan eli omintakeinen 5-kielisen kanteleen sulkusoittoperinne vielä 190o-luvun puolivälissä (Tenhunen 2010: 230-231).

Arkistonauhojen sävelmistöstä ylivoimainen enemmistö on polkkia ja valsseja. Ilmeisesti nämä tanssilajit olivat suosituimpia siinä vaiheessa, kun tikkusoitto alkoi harvinaistua. Ala-Könni (1986: 37) kirjoittaa kanteletta käytetyn myös läntiseen perinteeseen kuuluvissa häissä, jolloin soittajien ohjelmistoon ovat kuuluneet muun muassa morsiuspolskat. Valitettavasti arkistonauhoilta ei löydy yhtään polskaa sulkutekniikalla soitettuna, mikä johtunee keruuajankohdan myöhäisyydestä.

Melodiasoiton lisäksi arkistonauhoilla voi kuulla kanteleen tikkusoittoa pelimannimusiikin säestyksessä. Säestyssoittoa sisältävää musisointia on tallennettu muun muassa Keski-Suomesta Kannonkosken pelimanneilta (Kper A-K 1595) ja Hämeestä 1930-1940-luvuilla aktiivisesti esiintyneeltä Aarnion sisarukset -yhtyeeltä (1993). Lisäksi tikkusoiton tiedetään olleen yleinen säestystapa ainakin Etelä-Pohjanmaan Järviseudulla (Saha 2006: 412). Tikulla säestäminen toteutettiin sulkutekniikalla samaan tapaan kuin melodiasoittokin mutta siten, että sammuttavia sormia käytettiin ainoastaan sulkuotteiden muodostamiseen eli sointujen tuottamiseen, ei näppäilemiseen. Säestyssoittoa ei toistaiseksi ole juurikaan tutkittu, eikä itsellänikään ole ollut mahdollisuutta perehtyä asiaan tarkemmin tämän artikkelin puitteissa.

\section{Vuoropuhelua perinteen kanssa - tikkusoiton tutkiminen musisoimalla}

Kansanmusiikin alan taiteellisissa jatkotutkinnoissa on usein sellainen asetelma, että tutkimuskysymyksessä yhdistyvät juurien etsintä ja toisaalta pyrkimys johonkin uuteen ja ennen kokemattomaan (Saha 2010: 90). Omalla kohdallani voin samaistua tähän: tikkusoittoperinteeseen syventyminen kumpuaa tarpeesta 
ymmärtää menneisyyttä ja olla osallisena tradition jatkumisessa, mutta samanaikaisesti olen aktiivisesti säveltänyt ja kehittänyt kanteleelle uusia, kokeellisia soittotekniikoita. Olen myös ammentanut tikkusoittoperinteestä inspiraatiota uuden musiikin luomiseen.

Valmistelin tikkusoiton perinnetyyleihin pohjautuen toisen tohtorintutkintokonserttini "Hienohelma ja hyppivä puuhevonen - rouheaa perinnemusiikkia kanteleilla" (Helsinki 26.9.2014). Konsertissa soitin sekä soolona että eri kokoonpanojen kanssa yhteensä kolmetoista sävelmää, jotka oli tallennettu arkistonauhoille viideltä eri pelimannilta. Tässä artikkelissa analysoimani kolmen soittajan versiot Hienohelma-kappaleesta olivat konsertin ohjelmistossa, ja niistä tehdyt konserttitallenteet ovat nähtävillä videoklippien muodossa. Videomateriaali ei siis tässä ole analyysin kohteena. Sen tehtävänä on pikemminkin havainnollistaa lukijalle tikkusoittotyylejä ja tuoda ilmi, miten tämän päivän kansanmuusikko voi sekä työskennellä arkistomateriaalin parissa että esittää siihen perustuvaa musiikkia omista lähtökohdistaan käsin.

Koska soittaminen vanhakantaista tikkusoittoperinnettä edustavien pelimannien kanssa ei ole ollut mahdollista, linkkinä traditioon ovat olleet arkistotallenteet. Sain useaan otteeseen musisoida mestaripelimanni ja soitintutkija Kari Dahlblomin (1955-2017) kanssa, mutta hänen tyylinsä edusti nykyaikaisempaa tikkusoiton estetiikkaa. Perinteisten soittotapojen opettelu arkistotallenteiden pohjalta on hyvin erilaista kuin mahdollisuus kohdata pelimanni elävänä ja tutustua hänen soittotapaansa yhdessä musisoiden. Arkistonauhalle tallennetut materiaalit ovat vain välähdys kunkin pelimannin soittotavasta ja kenties persoonastakin, jos tallenteilla on mukana puhetta.

Kuten historiallinen kansanmusiikki lähtökohtaisesti, myös tikkusoitto oli kuulonvaraista perinnettä: kenenkään soittajan ei tiedetä käyttäneen nuotteja. Siksi työskentelin itsekin siten, että opettelin ensin kappaleet korvakuulolta arkistonauhojen kanssa soittamalla ja vasta tämän vaiheen jälkeen tein transkriptiot. Tällaista informaation kulkua, jossa tieto kulkee kuulonvaraisena äänitteen välityksellä, nimitetään sekundaarisesti muistinvaraiseksi (Kurkela 1991: 90; Ong 2002 [1982]: 11).

Kun aloitan työskentelyn arkistotallenteella olevan kappaleen kanssa, kuuntelen sitä ensin lukuisia kertoja. Samalla voin sitoa musiikin sen historialliseen kontekstiin ja käydä mielessäni läpi millaisissa ympäristöissä, mistä syystä ja 
kenen toimesta kyseistä kappaletta on saatettu soittaa. Musisoivan tutkijan on näin mahdollista siirtyä ajatuksissaan kuvitteelliselle kentälle ja olla mukana tilanteissa, joissa tutkittava traditio elää.

Seuraava vaihe on selvittää musiikin toteutustapa ja ryhtyä soittamaan arkistotallenteen mukana. Kappaleessa käytetyt sulkuotteet pystyy yleensä päättelemään kuuntelemalla. Otteen laajuuden paljastaa se, mitkä kielet soivat vapaina sen ala- ja yläpuolella. Otteen perusteella taas voi saada selville, mitä vasemman käden sormia soittaja käyttää näppäillessään. Näiden suuntaviivojen selvittämisessä tallenteiden mukana soittaminen on osoittautunut tärkeäksi menetelmäksi. Melodian hahmottumisessa auttaa sormituntuma, sillä tikulla soitetut ja sormilla näppäillyt äänet rytmittyvät tietyn kaavan mukaan: yleensä kahdeksasosarytmit soitetaan tikulla, kun taas kuudestoistaosarytmeissä tikulla soitetut ja vasemman käden sormilla näpätyt äänet vuorottelevat. Kun kokeilen sulkuotteita omilla sormillani, selviää nopeasti esimerkiksi se, onko kyseinen melodia mahdollista toteuttaa päättelemilläni otteilla, tai tekikö arkistotallenteen soittaja välillä perusotteistaan poikkeavia ratkaisuja. Tallenteiden mukana soitettaessa melodia, sulkuotteet ja tekninen toteutus paljastuvat ikään kuin yhtenä kokonaisuutena ja kappaleen myös oppii saman tien ulkoa. Transkriptiot teen vasta tämän vaiheen jälkeen, ja niiden avulla voi syventyä enemmän yksityiskohtiin.

Kuten jo aiemmin totesin, arkistotallenteilla kuulemieni kymmenen soittajan tapa käyttää tikkua vaihtelee paljon: jotkut soittavat lähes yksiäänisesti ja toiset "roiskivat" tikulla niin, että soitto on varsin moniäänistä, jolloin melodian hahmottaminen kolmisointusatsista voi olla hankalaa. Useimmiten melodiasäveleksi hahmottuu pariäänen tai soinnun korkein sävel, mutta aina ei tämäkään tunnu pitävän paikkaansa. On todennäköistä, että hahmotan melodian toisin kuin arkistonauhan soittaja. Jos kirjoitan melodian ylös tai opetan sitä eteenpäin, kyseessä ei ole soittajan tulkinta melodiasta, vaan oma näkemykseni siitä.

Arkistomateriaaliin perehtymisen kautta avautunut ymmärrys tikkusoiton moninaisuudesta on vaikuttanut omaan soittooni, johon on tullut uusia elementtejä pelimannien tyyleistä. Soittotyylien selvittämiseen ja omaksumiseen arkistotallenteilta tarvitaan erilaisia lähestymistapoja. Etnomusikologi Tuuli Talvitie, jonka väitöstutkimukseen sisältyi perehtymistä eteläpohjalaisen viulunsoiton arkistomateriaaliin, on pohtinut soittotyylin tiedostettua omaksumista. Toisen soittajan tyyliä ei voi omaksua täysin, mutta on mahdollista oppia soittamaan 
jonkun tapaan, jolloin kyseessä on enemmän oma tulkinta toisen henkilön soitosta. Talvitie-Kellan (2010: 58) mukaan tyylin omaksumisessa olennaisia elementtejä ovat "kuunteleminen, soittaminen ja (soittamalla) imitoiminen". Näitä kaikkia olen hyödyntänyt omassa tutkimuksessani. Suureksi avuksi ovat osoittautuneet tietokoneohjelmat, jotka mahdollistavat soiton hidastamisen sekä soivan sävelkorkeuden muuttamisen. Imitoiminen on tärkeä osa toisen soittajan tyyliin perehtymistä, mutta kappaleen hallitseminen saman kuuloisesti ei välttämättä vielä tarkoita soittotyylin syvempää hahmottamista. Imitoinnista seuraava askel on ymmärtää, millaisista musiikillisista seikoista soittotyyli muodostuu, ja kyetä varioimaan musiikkia näillä elementeillä samaan tapaan kuin soittaja.

Jokainen arkistomateriaalin parissa työskentelevä muusikko päätyykin pohtimaan, missä määrin hän haluaa pyrkiä toistamaan kuulemaansa sellaisenaan ja minkä verran hänen omat taiteelliset mieltymyksensä vaikuttavat arkistotallenteilta opeteltuun musiikkiin ja sen esittämiseen. Vanhan musiikin parissa toimivan muusikko-tutkija Assi Karttusen (2013: 160) mukaan "objektiivisen historiallisen totuuden etsimisen sijaan esittäjä tiedostaa olevansa läsnä historiallisen aineiston parissa pitkään eläneenä, sitä kommentoivana, muuntavana ja valikoivana toimijana". Vaikka olen halunnut oppia soittamaan ja ymmärtämään arkistotallenteilla kuulemiani erilaisia soittotyylejä, voin kyseisen ohjelmiston esittäjänä itse päättää ja perustella omat taiteelliset valintani. Kun työstin arkistotallenteilta oppimaani musiikkia esitettäväksi tutkintokonserttiini, en halunnut yrittää toistaa pelimannien soittoa sellaisenaan. Sen sijaan toin esiin myös omista lähtökohdistani kumpuavaa perinnettä, jossa kuitenkin kuuluivat pelimannien soittotyylien tärkeimmät piirteet. Saha (1996: 349) korostaakin soittotyylien opettelussa luovuutta: hänen mielestään ei tule tavoitella kuviteltua autenttisuutta, vaan tyylejä voi lähestyä uutta luovasti, kunhan selventää ensin itselleen ne puitteet ja lainalaisuudet, joiden sisällä luova toiminta voi tapahtua.

Suhteessani arkistomateriaaliin ja historiallisiin soittotapoihin näen yhtäläisyyksiä vanhan musiikin toimijoihin, jotka pohtivat samankaltaisia kysymyksiä kuin itse olen tutkimusta tehdessäni kohdannut. Vanhan musiikin esittäjien keskuudessa syntyneen HIP-liikkeen (Historically Informed Performance) piirissä hyödynnetään soitettavan musiikin syntyajan esityskäytänteitä erilaisiin historiallisiin lähteisiin perustuen. HIP-liikkeen sisälläkin on erilaisia lähestymistapoja, ja liikkeeseen on kohdistunut myös voimakasta kritiikkiä liittyen esimerkiksi 
autenttisuuden tavoitteluun. (Haynes 2007: 10.) Vanhaa musiikkia esitettäessä käytetään usein periodisoittimia, jotka ovat joko alkuperäisiä soittimia tietyltä historialliselta ajalta tai niiden rekonstruktioita. Monet kansanmuusikotkin haluavat soittaa vanhoja soittimia tai niiden jäljitelmiä. Tällaiset instrumentit voivat muun muassa sointinsa puolesta johdattaa muusikkoa ymmärtämään syvällisemmin erilaisten traditioiden olemusta sekä toisaalta innoittaa myös uuden musiikin luomiseen.

\section{Arvi Pokela, Alfred Backman ja Aarne Moisio}

Koska käsittelen tutkimuksessani soittajien tyylejä, on olennaista hieman pohtia, mitä sana tyyli tässä tapauksessa tarkoittaa. Etnomusikologi Pirkko Moisalan (1993: 7-16) mukaan tyyli-käsitteen merkitys on kiinni siitä, miten tutkija haluaa sitä käyttää, mutta tyylintutkimuksessa pyritään kuitenkin aina löytämään "tyylin määrittävät ominaispiirteet, tyylin kriteerit". Nämä kriteerit on etsittävä tutkittavasta aineistosta, eikä niitä voi tietää etukäteen. Omakohtaisuus eli soittamalla kokeileminen ja imitoiminen ovat Moisalan mielestä tutkijalle olennaisia työskentelytapoja soittotyyliä analysoitaessa.

Tärkeä soittotyyliä koskeva lähdeteos suomalaisessa kansanmusiikin tutkimuksessa on jo aiemmin mainitsemani Hannu Sahan (1996) väitöskirja Kansanmusiikin tyyli ja muuntelu. Tämän artikkelin teeman kannalta Sahan näkemykset ovat paikkansapitäviä, joten sovellan niitä sellaisenaan osaksi taiteellista tyylintutkimusta.

Saha väittää, että tyyliä tarkasteltaessa musisoinnin sisältöjä määrittävät sekä sosiaalisessa toiminnassa opitut rajoitukset että yksilön itsensä normittamat mahdollisuudet. Hän näkee tämän vuorovaikutuksena, jossa sosiaalinen toiminta on kommunikatiivista ja yksilöllinen innovatiivista. (Saha 1996: 75.) Tässä artikkelissa keskityn soittajien henkilökohtaisiin soittotyyleihin, jotka perustuvat yksilöllisyyteen ja innovaatioihin. Vaikka tikkusoitosta näkee käytettävän myös nimitystä tikkutyyli, ajattelen Sahan (1996: 169) ja Dahlblomin (2011: 32) tapaan tikkusoittoa enemmän tekniikkana kuin tyylinä. Tikkusoitto perustuu sulkutekniikkaan, jossa tikku on soiton apuväline. Soittajien henkilökohtaiset tyylit taas 
syntyvät persoonallisista eroista, tavoista, joilla kukin soittaja toteuttaa tekniikkaa.

Sahan harjoittaman tyylintutkimuksen metodologiaan on vaikuttanut muun muassa etnomusikogi Mantle Hoodin teos The Ethnomusicologist (1971). Koska soittotyyli on aina sidoksissa kulttuuriseen kontekstiin, sitä säätelevät erilaiset normit. Näin ollen yksi tyylin taustatekijä on yleinen mielipide eli konsensus, jonka Hood jakaa kolmeen kategoriaan, musiikilliseen, kulttuuriseen ja sosiaaliseen. Ne ovat jatkuvassa vuorovaikutuksessa keskenään. Hood kirjoittaa, että keskustellessaan keskenään muusikot tuntuvat asiaa tarkemmin määrittelemättäkin olevan yksimielisiä siitä, mitä tyylillä tarkoitetaan, kun taas tutkijat erottavat tyylistä yhden tai useamman tyylipiirteen, joihin he keskittyvät. (Hood 1971: 296-301.) Näin ollen muusikot ja tutkijat tapaavat usein lähestyä aihetta eri lähtökohdista. Tätä tutkimusta tehdessäni olen hyödyntänyt sekä tutkijan että muusikon näkökulmaa: soittaen tehdyt havainnot ja tutkijan otteella analysoidut huomiot ovat kulkeneet rinnakkain ja sekoittuneet, tukien ja syventäen toinen toistaan.

Soittotyylianalyysini kohteena on kolme erilaista tikkusoittajaa: Arvi Pokela, Alfred Backman (1885-1973) ja Aarne Moisio (1912-1988). Saarijärvellä elänyt Arvi Pokela nostettiin näkyvästi esiin viimeisenä tikkusoittoperinteen edustajana ja nimitettiin mestaripelimanniksi Kaustisen kansanmusiikkijuhlilla vuonna 1983. Pokelan soittoa on taltioitu runsaasti Kansanmusiikki-instituutin arkistoon, ja hänen soitteistaan julkaistiin postuumisti levy Saarijärven kantele vuonna 1991. Pokelan tunnettuuden ja näkyvyyden johdosta hänen soittotyylinsä on kanteleensoittajien piirissä muodostunut ikään kuin standardiksi, johon kaikki tikkusoittoon vähänkin perehtyneet soittajat ovat tutustuneet. Tämä on sikäli ymmärrettävää, että Pokela itse ehti opettaa tyyliään muutamille henkilöille, kuten ensimmäisille Sibelius-Akatemian kansanmusiikin osaston opiskelijoille vuonna 1984. Häneltä on myös taltioitu soittoa useita tunteja, kun taas muiden pelimannien osalta arkistomateriaalin määrä rajoittuu kahteen tai kolmeen kappaleeseen. Asialla on kuitenkin kääntöpuolensa: kun jokin tietty soittotapa henkilöityy yhteen pelimanniin, koko ilmiö saatetaan nähdä tyylillisesti kapeaalaisempana kuin se on oikeasti ollut. Tikkusoiton kohdalla moni taitaja unohtui arkistojen kätköihin, eikä tultu ajatelleeksi, että eläviä soittajia olisi voinut löytyä vielä Pokelan jälkeenkin. 
Arvi Pokelaan verrattuna Alfred Backman ja Aarne Moisio ovat jääneet varsin tuntemattomiksi. Heidän soittotyylejään ei ole aikaisemmin tutkittu, ja musiikkitallenteitakin heiltä on olemassa hyvin vähän. Tämä on jossain määrin saanut minut pohtimaan Erkki Ala-Könnin toimintaa kansanperinteen tallentajana. Tiedostan, ettei Ala-Könnin intresseissä ollut taltioida pelkästään soittoa vaan ylipäätään kansanperinnettä ja että hänen keruutyönsä oli kaikessa laajuudessaan vertaansa vailla oleva kulttuuriteko. Silti uskallan ihmetellä, miksi Ala-Könni taltioi näiltä taitavilta soittajilta vain kahdesta kolmeen kappaletta kultakin.

Arvi Pokela oli oppinut kanteleensoittotaidon isältään Otto Pokelalta. Nuorena Pokela soitti kanteleen lisäksi aktiivisesti haitaria muun muassa Top Hat -yhtyeen kanssa häissä ja talkootansseissa. Tilanhoidon ja perheen perustamisen vuoksi soittamiseen tuli pitkä tauko, mutta siirrettyään maatilan pojalleen Pokela innostui soitosta uudestaan, mihin vaikutti myös kanteleen arvostuksen kasvaminen. (Lindblad 1992: 149.)

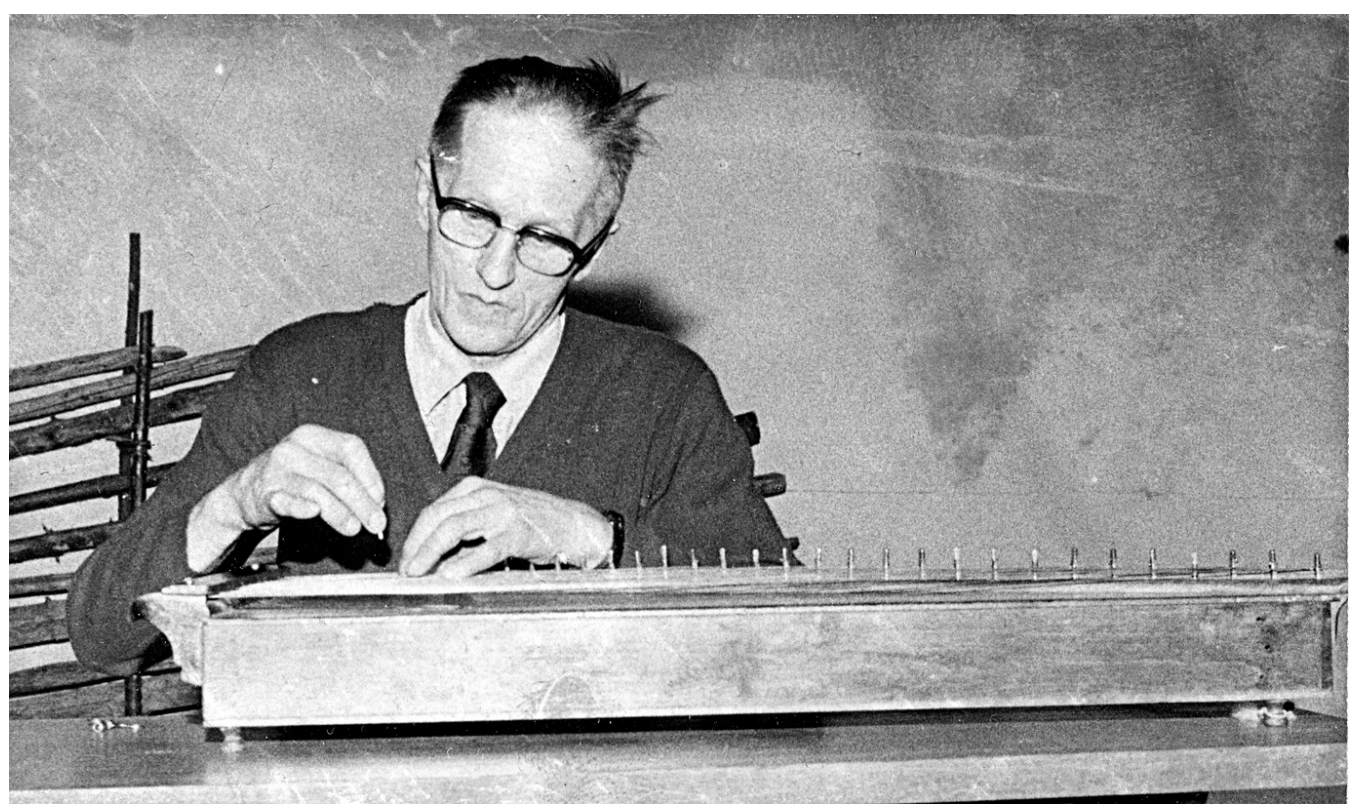

Kuva 2: Arvi Pokela. Saarijärven museon kuva-arkisto. 
Pokelan soitto on kepeän svengaavaa, helisevää ja tanssillista. Ohjelmisto sisältää polkkia, valsseja, jenkkoja ja masurkkoja. Kanteleen vire on nauhoilla C-duuri, ja hän käyttää kahta sulkuotetta (ks. Taulukko 2). Joskus hän nostaa kieltä sammuttavan peukalonsa ilmaan väistämään, jotta saa soitettua tietyn melodiasävelen tikulla. Säestyskielten (I, IV ja v aste) käyttö on monipuolista. Pokela soittaa niitä kaikille iskuille, mikä antaa musiikille omanlaisensa poljennon. Persoonallisin piirre Pokelan soitossa on tiheästi viljelty vasemman käden sormilla näppäileminen, joka tunnetaan nimellä höystö (Lindblad 1992: 150). Pokela käyttää höystämiseen vasemman käden etu- ja keskisormea, joiden rytmitys vuorottelee ja varioi koko ajan. Näppäiltävät sävelet ovat osin melodian runkoa, jolloin hän saattaa käyttää myös peukaloa, osin taas varsinaisen melodian ulkopuolisia ääniä. Pokela soittaa tikulla runsaasti pariääniä, ja näiden sekä höystöjen yhdistelmä saa aikaan sen, että kuulokuva hänen soitostaan on helisevä ja alati muunteleva ${ }^{1}$.

Keski-Suomessa Kannonkoskella elänyt Alfred Backman oli alueella tunnettu kanteleen taitaja, joka soitti isoa kanteletta sekä näppäillen että sulkutekniikalla. Hän osallistui monen muun soittajan tavoin Erkki Ala-Könnin järjestämiin radionauhoituksiin Kannonkoskella vuonna 1954, jolloin häneltä tallennettiin kolme kappaletta: Hienohelma, Rankan eli Returankan polkka sekä yksi valssi. (Dahlblom 2011: 166-185.) Näistä taltioinneista kaksi ensimmäistä on kuultavissa Kanteleliiton julkaisemalla Rankan polkka -levyllä (2012), joka sisältää keskisuomalaista kanteleperinnettä ${ }^{2}$.

Kuulokuva Backmanin soitosta on rytmikäs ja rouhea. Hänellä on käytössään kaksi sulkuotetta, jotka ovat samat kuin Aarne Moisiolla (ks. Taulukko 2). Kan-

I Ääni- ja videoesimerkit saatavilla osoitteessa http:/ /www.etnomusikologia.fi/p/av2018.html Ääninäyte 1: Heramäen pukki Arvi Pokelan soittamana (Pokela 1991). Videoklippi 1: Pokelan soitteeseen pohjautuva Heramäen pukki Pauliina Syrjälän esittämänä. Hienohelma ja Hyppivä puuhevonen -konsertti 26.9.2014.

2 Ääni- ja videoesimerkit saatavilla osoitteessa http://www.etnomusikologia.fi/p/av2018.html Ääninäyte 2: Hienohelma Alfred Backmanin soittamana (Kper A-K o054). Videoklippi 2: Backmanin soitteeseen pohjautuva Hienohelma Pauliina Syrjälän ja Maija Kauhasen esittämänä. Hienohelma ja Hyppivä puuhevonen -konsertti 26.9.2014. 
tele on viritetty D-duuriin, ja diskanttikielten lisäksi hän soittaa sulkutekniikkaa käyttäessään kolmea bassokieltä: I aste, IV aste ja V aste. Näistä I aste eli D on punottu bassokieli, muut korkeampia diskanttikieliä. Kaikki Backmanin vasemman käden sormilla näppäilemät äänet kuuluvat melodiaan, ja hänen näppäilyyn käyttämänsä sormet ovat keskisormi, etusormi ja peukalo. Yksi Backmanin soittotyylin ominaispiirre on tikulla ylöspäin vedettävät kolmisoinnut, joita kutsun sointuvetäisyiksi. Sointuvetäisy on mahdollinen silloin, kun melodia etenee kolmisoinnulla ylöspäin. Sointuvetäisy soitetaan siten, että kolmisoinnun äänet vetäistään soimaan yhdellä tikun liikkeellä. Tällä tavoin soitetun kolmisoinnun rytmi on soittajilla yleensä $1 / 16+1 / 16+1 / 8$. Sointuvetäisy tuo erilaisen rytmisen sävyn tikkusoittoon, jossa kuudestoistaosarytmit soitetaan yleensä tikkua ja näppäilyä vuorottelemalla. Kymmenen arkistonauhoilla musisoivan pelimannin joukosta sointuvetäisyjä käyttivät runsaasti Backman, Aarne Moisio ja Salomo Korhonen sekä satunnaisemmin Arvi Pokela.

Vilppulalainen Aarne Moisio oli arkistoaineiston perusteella taitava kantelepelimanni, joka soitti kanteletta muun muassa tansseissa ja kyläjuhlissa (Dahlblom \& Nieminen 2012: 26). Erkki Ala-Könni haastatteli Moisiota erilaisista perinneaiheista useita tunteja, mutta musiikin osuus jäi valitettavan pieneksi. Arkistonauhalta löytyy vain kaksi polkkaa: Hienohelma sekä Akkojen polkka eli Hytkypolkka (Kper AK 4510), jotka on julkaistu Rankan polkka -levyllä (2012)3.

Moision soitinvalikoimaan kuuluivat kanteleen lisäksi myös viulu, rummut, sähköurut ja banjo, jota hän soitti Vilppulan pelimanneissa. Hän myös sävelsi aktiivisesti. (Dahlblom \& Nieminen 2012: 26.) Ilmeisesti Moisio piti kanteletta vanhanaikaisena soittimena, eikä hän tästä syystä nähnyt tarvetta korostaa soittotaitoaan. (Nieminen h2014.)

\footnotetext{
3 Ääni- ja videoesimerkit saatavilla osoitteessa http:/ /www.etnomusikologia.fi/p/av2018.html Ääninäyte 3: Hienohelma Aarne Moision soittamana (Kper A-K 4510). Videoklippi 3: Yhdeksänhenkinen kanteleyhtye esittää Moision soitteeseen pohjautuvan Hienohelman. Hienohelma ja hyppivä puuhevonen -konsertti 26.9.2014.
} 
Moision soitto on sujuvaa ja rytmisesti tarkkaa. Hän soittaa selkeästi siten, että melodia on helppo hahmottaa. Moisiolla on käytössään samat sulkuotteet kuin Backmanilla (ks. Taulukko 2). Moision kantele on viritetty G-duuriin, eikä hän käytä bassokieliä. Moision soitossa vasemman käden sormien (peukalo, etusormi, keskisormi) soittamia näppäilyitä on runsaasti, ja ne ovat melodiaan kuuluvia ääniä. Hän soittaa melodiat tarkasti, lähes yksiäänisesti. Mukana on korkeintaan yksi melodian ulkopuolinen ääni, yleensä alapuolinen terssi. Toisessa nauhalle soittamassaan kappaleessa, Akkojen polkassa, Moisio käyttää sointuvetäisyjä, Hienohelmassa taas ei. Tämä poikkeaa Backmanista, jonka kohdalla sointuvetäisyjä esiintyy runsaasti molemmissa häneltä taltioiduissa kappaleissa.

\section{Soittaiien käyttämät sulkuotteet G-vireisen kanteleen kielille merkittynä:}

Sammuttavat sormet: 5=pikkusormi, 4=nimetön, 3=keskisormi, 2=etusormi ja 1=peukalo

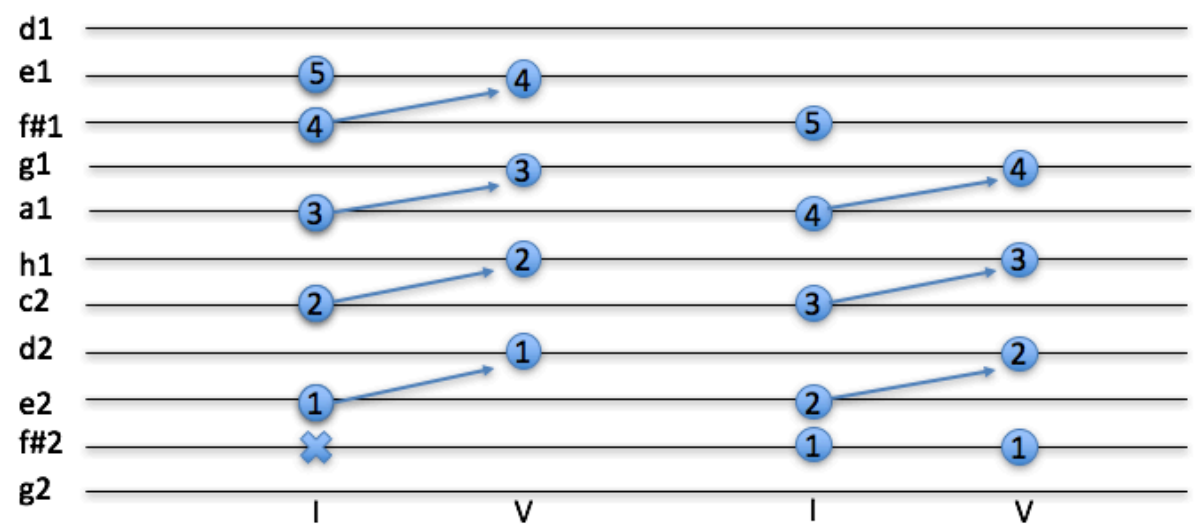

Alfred Backmanin ja Aarne Moision sulkuotteet

Otteen vaihtuessa I -> V: kaikki sormet siirtyvät soittajasta poispäin paitsi pikkusormi, joka nousee ilmaan

$X=$ tarvittaessa kieli sammutetaan peukalon syriällä
Arvi Pokelan sulkuotteet

Otteen vaihtuessa I -> V: peukalo jää paikalleen ja pikkusormi nousee ilmaan, muut sormet siirtyvät soittaiasta poispäin

Taulukko 2: Soittajien käyttämät sulkuotteet. 


\section{Kolme erilaista Hienohelmaa}

Hienohelma eli Koko maailman polkka on yleisesti tunnettu traditionaalinen sävelmä, jota on soitettu eri puolilla Suomea. Hienohelman tahtilaji on 2/4, ja se on duurisävelmä, jossa on kaksi kahdeksan tahdin pituista repriisiä eli A- ja B-osat. Sävelmä on ollut suosittu myös tikkusoittajien keskuudessa, sillä siitä löytyy arkistonauhalle soitettu versio neljältä eri soittajalta. Kullakin pelimannilla on melodiasta omat variaationsa, mutta sen voi kuitenkin tunnistaa samaksi sävelmäksi. Pokelan levyn (1991) kannessa kappaleen nimi ei ole Hienohelma vaan Heramäen pukki: levyllä Pokela kertoo sen olevan "aito saarijärveläinen kappale", joka on nimeltään Ootkos velikulta pukkia nähny tuolla Heramäen rinteessä. Kutsun silti tässä tekstissä myös Pokelan soittamaa versiota Hienohelmaksi.

Transkriptiot on tehty sellaisella tarkkuudella, että soittajien väliset variaatiot ja tyylipiirteet on mahdollista erottaa hyvin. Pelimannimusiikkia soitettaessa ja analysoitaessa tuntuu tarpeelliselta hahmottaa kappaleen melodiarunko. Olen merkinnyt transkriptioon melodiaksi tulkitsemani sävelet nuotein, joissa on suuremmat päät. Jotta nuottikuva säilyisi havainnollisena, en ole halunnut kirjoittaa yksityiskohtaisesti auki esimerkiksi kaikkea mikrotason rytmiikkaa. Eri versioiden välisen vertailun helpottamiseksi olen transponoinut kaikki kolme Hienohelmaa G-duuriin, joka on tikkusoitossa nykyisin eniten käytetty vire sekä Moision käyttämä alkuperäinen vire. Arkistotallenteella Pokelan soittaman Hienohelman vire on C-duuri ja Backmanilla D-duuri. Hienohelman eri versiot antavat mahdollisuuden tarkastella soittajien tyylejä neljän elementin kautta: 1) sulkuotteet, 2) melodia ja sen muuntelu, 3) rytmiikka ja 4) bassokielten käyttö.

Hienohelma-kappaleessa kukin soittaja hyödyntää kahta sulkuotetta, I ja V. Kuten soittajia käsittelevässä kohdassa tuli esiin, Backman ja Moisio käyttävät keskenään samanlaisia sulkuotteita, mutta Pokelan otteet ovat erilaiset. Transkriptiosta voi nähdä, että soittajat vaihtavat sulkuotetta samassa kohdassa. Tästä huolimatta sointutehot voivat kuulostaa erilaisilta: Backmanin versiossa ensimmäisen B-osan kolmannessa tahdissa tulee esiin kuulokuva IV-sointutehosta, vaikka sulkuote ei muutu. Tämä johtuu siitä, että Backman soittaa terssinä otteen kaksi korkeinta ääntä, c2 ja e2, jotka ovat IV-sointuun kuuluvia ääniä. Vaikutelmaa korostaa Backmanin kyseisessä tahdissa näppäämä bassoääni, joka on c. 
Sulkuote ei siis aina tarkoita tiettyä sointua, vaan yksi sulkuote voi mahdollistaa useamman soinnun säveliä tikun liikkeen laajuudesta riippuen.

Soittajien käyttämät sulkuotteet määrittävät myös melodialinjaa, joka on heillä kaikilla pidempien fraasien osalta samankaltainen. Fraasien sisällä tapahtuvissa yksityiskohdissa eri soittajien välinen variaatio on kuitenkin runsasta. Pokelan soittoa kuunnellessa melodiaa on hetkittäin vaikea hahmottaa, mikä johtuu vasemman käden sormien näppäilyiden, eli Pokelan tyylistä puhuttaessa höystöjen, runsaasta käytöstä sekä moniäänisyydestä. Kun melodiaa soittaa arkistotallenteen mukana, höystöjen loogisuus avautuu paremmin kuin pelkästään kuuntelemalla. Pokela näppää vasemman käden keski- ja etusormia vaihdellen tietynlaista kuviota tikulla soitetun melodian rungon sekaan. Usein hän varioi kuviota muodossa etusormi-keskisormi, etusormi-keskisormi-etusormi tai etusormi-keskisormi-etusormi-etusormi. Nämä näppäillen soitetut sävelet hahmottuvat joko melodian osiksi tai sen ulkopuolisiksi koristeluiksi. Lisäksi Pokela soittaa paljon moniäänisesti eli vetäisee tikulla soimaan useamman äänen kerrallaan. Usein melodiasävel on soivan satsin ylin ääni, mutta esimerkiksi lopukkeissa tämä yleistys ei pidä paikkaansa.

Moision soittaessa Hienohelmaa melodia tulee esiin varsin selkeästi, vaikka pariääniäkin on silloin tällöin: eniten niitä kuuluu lopukkeissa. Moisio näppäilee vasemman käden sormilla tiheästi, mutta kyseiset sävelet hahmottuvat melodian osaksi, toisin kuin Pokelan höystötyylin kohdalla. Pokela käyttää Hienohelmassa näppäilyyn vasemman käden etu- ja keskisormea, Moisio soittaa näiden lisäksi myös peukalolla. Backmanin soittamana melodia ei tule esiin yhtä selkeänä kuin Moisiolla, mutta se on kuitenkin huomattavasti Pokelaa helpommin hahmotettavissa. Backmanin soitossa kuuluu pariääniä jonkin verran, mutta melodiaa selkeyttää vasemman käden näppäilyjen funktio melodian osana kuten Moisiollakin. Moision tapaan myös Backman käyttää näppäillessään vasemman käden keskisormea, etusormea ja peukaloa, mikä johtuu soittajien samanlaisista sulkuotteista. Pokelan sulkuotteet ovat erilaiset, jolloin asteikon tietyn äänen näppää eri sormi kuin Backmanilla tai Moisiolla. Pokela ei hyödynnä Hienohelmaa soittaessaan peukaloa siksi, että hänen sulkuotteissaan peukalon näppäämä ääni olisi asteikon seitsemäs sävel, joka ei kuulu Hienohelman perusmelodiaan. 
Yksi Backmanin soiton ominaispiirteistä ovat lisäksi sointuvetäisyt, joista kerron tarkemmin rytmiikkaa käsittelevässä kohdassa. Sointuvetäisyjen käyttö vaikuttaa osaltaan myös melodiaan, sillä melodia etenee vetäisykohdissa aina kolmisoinnulla. Tämä näkyy esimerkiksi siinä, että Moisiolla Hienohelman aloitustahti on melodisesti erilainen kuin muilla.

Melodian varioinnin määrä vaihtelee näiden kolmen soittajan välillä paljon. Moisio tekee melodiaan pieniä rytmisiä variaatiota, samoin Backman, mutta Pokelan Hienohelma on alati muunteleva. Soittamisen kautta on mahdollista todeta, että Pokelan muuntelu tapahtuu soittotavalle luonteenomaisin ja helposti toteutettavin keinoin. Tikkukäden liikerataa kasvattamalla tai pienentämällä voi vaikuttaa siihen, kuinka monta ääntä soi samanaikaisesti melodiasävelen kanssa, ja höystöjen osalta muuntelu toteutuu vasemman käden näppäilykuvioita vaihdellen.

Polkalle ominaisen rytmiikan mukaisesti melodia etenee niin Pokelan, Backmanin kuin Moisionkin soittamissa Hienohelmoissa kuudestoista- ja kahdeksasosarytmeissä. Pokelalla ja Moisiolla rytmiikka on tiheämpää kuin Backmanilla. Heidän versioissaan on paljon kuudestoistaosarytmejä ja daktyylejä, jolloin kahdeksasosille osuvat sävelet soitetaan tikulla ja jälkimmäiset kuudestoistaosat aina vasemman käden sormilla näppäillen.

Moision soitto on rytmisesti hyvin selkeää ja samankaltaista molemmilla soittokierroksilla. Pokelan soitosta puolestaan nousee esiin höystöillä aikaansaatu tiheä rytminen kudelma, sillä kuudestoistaosarytmit kulkevat mukana joko melodian osana tai sen koristeina lähes koko ajan. Hänen rytmiikkansa on myös ajoittain kolmimuunteista: kuudestoistaosarytmit eivät aina ole tasaisia, vaan kallistuvat toisinaan triolien suuntaan, jolloin tikulla soitettu ääni on pidempi ja näpäten soitettu lyhyempi.

Backmanin soiton rytminen erityispiirre ovat sointuvetäisyt. Hän käyttää niitä runsaasti etenkin A-osassa, jonka jokainen neljän tahdin mittainen fraasi käynnistyy sointuvetäisyllä. Tämä määrittää rytmiikkaa, sillä sointuvetäisyn alussa on aina rytmi $1 / 16+1 / 16+1 / 8$. Kuten sanottu, sointuvetäisyn kohdalla melodiassa on kolmisointu. B-osassa Backman tekee sointuvetäisyjä ainoastaan lopukkeessa. Muut Backmanin B-osan soitossa ilmenevät rytmiset eroavaisuudet kahteen muuhun soittajaan verrattuna ovat harvempi rytmiikka sekä pisteellisten rytmien käyttö. Backmanin soittama B-osa perustuu paljolti kahdeksasosarytmeihin, 
joista osa on pisteellisiä. Harvemmasta rytmiikasta johtuen B-osan melodialinja on huomattavasti staattisempi kuin Pokelalla tai Moisiolla, joilla kuudestoistaosarytmit eli sitä kautta tikun ja näppäyksen vuorottelut mahdollistavat liikkuvamman melodian.

Bassokielten käytössä soittajien välillä on suuria eroja. Moisiolta tallennetuissa kappaleissa ei kuulu bassokieliä, kun taas Pokela ja Backman soittavat molemmat bassoja. Kun tiheärytmisessä kappaleessa kuten polkassa on mukana bassoja, ne korvaavat melodian säveliä, sillä bassoäänet soitetaan tikulla jollekin kahdeksasosalle. Siitä kohtaa jää puuttumaan melodiaääni, koska tikulla ei voi soittaa sekä diskantti- että bassokieltä samanaikaisesti. Bassot tuovat soittoon omanlaisensa sävyn, koska bassolla soitettu ääni hahmottuu säestysfunktion lisäksi myös osaksi melodiaa.

Useissa muissa tallenteissa Pokela soittaa bassoja myös iskuttomille tahdin osille, mutta Hienohelmassa bassot tulevat viimeisen B-osan kolmatta tahtia lukuun ottamatta aina iskuille. Pokela vähensi bassokielten käyttöä, kun huomasi tutkijoiden olevan erityisen kiinnostuneita höystöstä (Lindblad 1992: 152). Backmanin tyyli käyttää bassokieliä taas on omalaatuinen, sillä hänellä on toisinaan tapana soittaa yhden tahdin sisällä sama bassokieli kaksi kertaa: Hienohelmassa tämä tulee esiin A-osien lopukkeissa. Yleensä bassokieliä soitetaan harvemmin, sillä ne jäävät soimaan pitkäksi aikaa. Hienohelmassa Backman soittaa Pokelan tapaan bassoja iskuille, mutta bassojen soiton tiheydessä on eroa eri osien välillä, sillä esimerkiksi ensimmäisessä A-osassa basso tulee vasta lopukkeessa. Backmanin soittamissa B-osissa bassojen tiheydestä ja harvemmasta rytminkäsittelystä aiheutuu iskuja korostava poljento, kun taas Pokelan soitossa kuuluu painotuksia myös takapotkuille.

Edellä käsittelemieni elementtien lisäksi myös kappaleen muoto vaihtelee soittajilla jonkin verran. Kaikki kertaavat A-osan, mutta B-osien määrässä on variaatiota:

\begin{tabular}{|c|c|c|c|}
\hline Pokela: & 1. $\mathrm{AAB}$ & 2. $\mathrm{AAB}$ & 3. $\mathrm{AABB}$ \\
\hline Backman: & 1. $\mathrm{AAB}$ & 2. $\mathrm{AAB}$ & \\
\hline Moisio: & 1. $\mathrm{AABB}$ & 2. $А A B B$ & 3. $\mathrm{AABB}$ \\
\hline
\end{tabular}


Backman soittaa aina B-osan vain yhden kerran, Pokela puolestaan kahdella ensimmäisellä soittokierroksella kerran, mutta kahdella jälkimmäisellä kaksi kertaa. Voi siis päätellä, että kappaleen muotoa tarkasteltaessa B-osan kertausten määrä on muutoksille alttiimpi kuin A-osan kertausten.

Arkistoäänitteillä tapahtuva kappaleen muodon vaihtelu on huomioitu Hienohelman nuotissa seuraavasti: Moisiolta on nuotinnettu tallenteelta Hienohelmakappaleen ensimmäinen soittokierros А Ав , Backmanilta ja Pokelalta ensimmäinen soittokierros $\mathrm{AAB}$, sekä lisäksi toisen soittokierroksen B.
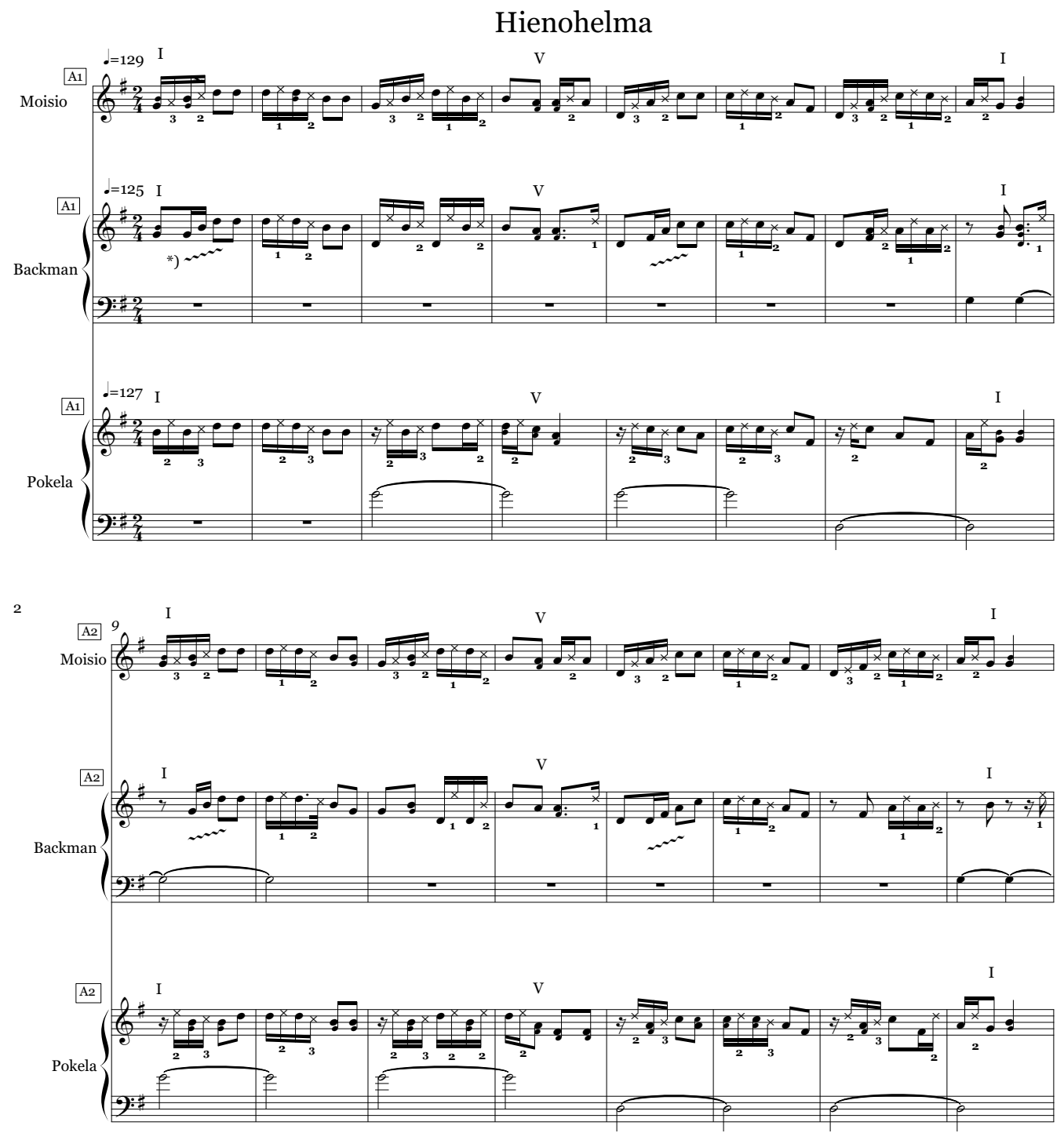

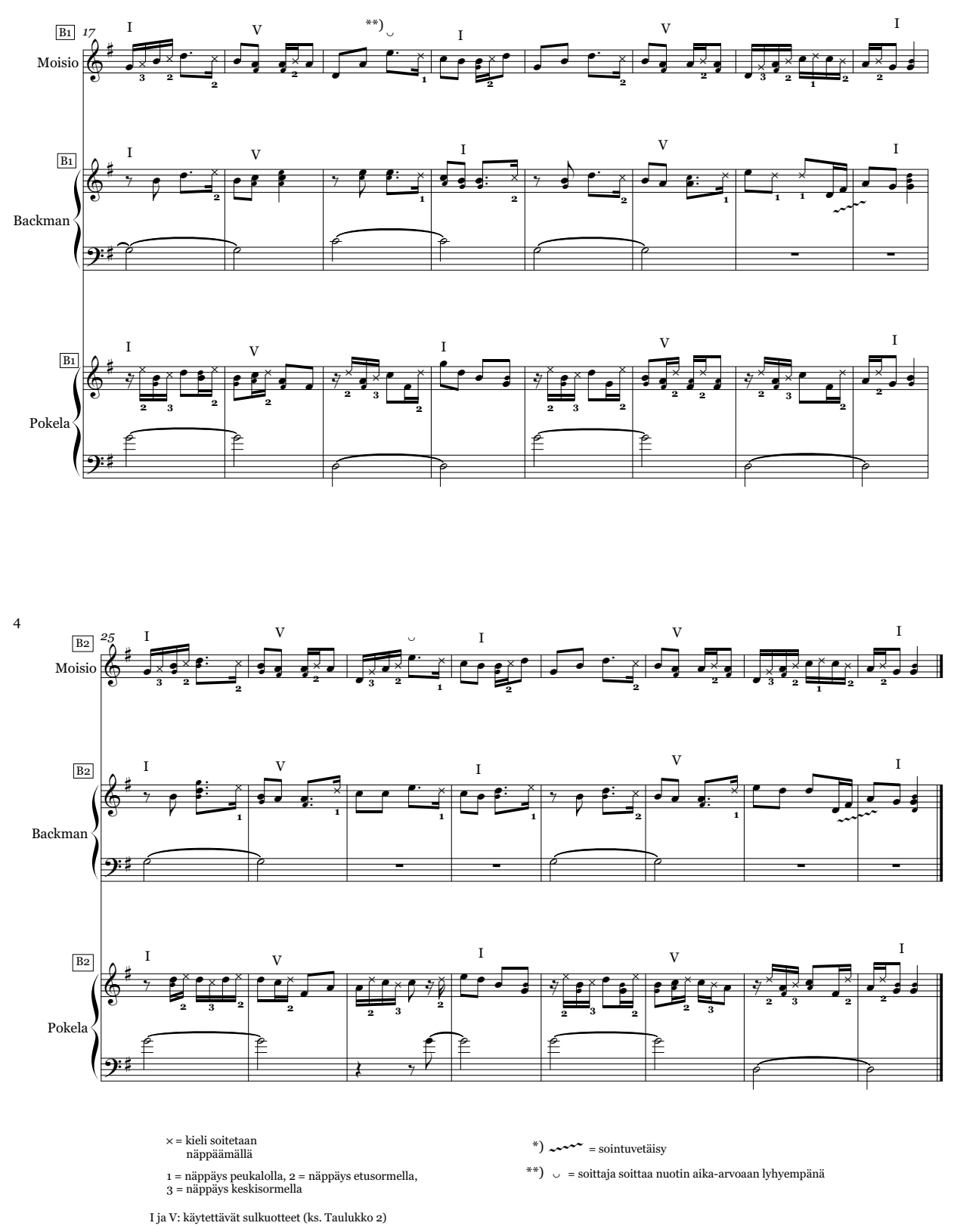

Nuottiesimerkki 1: Hienohelma Moision, Backmanin ja Pokelan soittamana. 


\section{Johtopäätökset}

Ennen tohtoriopintojen aloittamista olin perehtynyt ainoastaan Arvi Pokelan tyyliin, enkä ollut osannut ajatella, kuinka moninainen ilmiö tikkusoittoperinne on ollut. Kolmelta soittajalta tallennettujen Hienohelmojen myötä on avautunut mahdollisuus tarkastella, kuinka nämä pelimannit ovat toteuttaneet saman kappaleen kukin omalla tyylillään. Kuuntelemisen ja etenkin soittamisen seurauksena nämä versiot ovat näyttäytyneet lähes eri kappaleina. Nuottikuvan perusteella melodinen runko on sama, mutta soittotyylien vuoksi musiikillisissa lähestymistavoissa on suuria eroja. Ne vaihtelevat esimerkiksi bassojen puuttumisesta kokonaan (Moisio) runsaaseen bassojen käyttöön (Backman ja Pokela) tai tarkasta melodiasoitosta (Moisio) moniäänisen melodian jatkuvaan variointiin (Pokela).

Kolmen pelimannin soittotyylejä vertailtaessa huomio kiinnittyykin ennen kaikkea niiden erilaisuuteen. Moision ja Pokelan tyylit asettuvat tämän vertailun ääripäihin. Moisio soittaa melodiat hyvin selkeästi, usein lähes yksiäänisesti ja melko vähän varioiden, kun taas Pokelan soitto on paljolti moniäänistä ja koko ajan muuntelevaa. Erona on myös sorminäppäilyiden funktio: Moisiolla näppäilyäänet ovat osa kappaleen melodiaa, kun taas Pokela lisää sormillaan mukaan myös koristeääniä. Moisio ei käytä bassoja laisinkaan, Pokela sen sijaan soittaa niitä runsaasti. Backmanin tyyli sijoittuu monella tapaa Pokelan ja Moision tyylien välimaastoon. Backmanin melodiankäsittely on Pokelaa selkeämpää, mutta pariääniä on enemmän kuin Moisiolla. Pokelan tapaan myös Backman hyödyntää bassokieliä, mutta hän soittaa niitä toisinaan saman tahdin sisällä useamman kerran. Tämän lisäksi hänelle on ominaista sointuvetäisyjen aktiivinen käyttö. Pokelan ja Moision Hienohelmoista sitä tyylipiirrettä sen sijaan ei löydy.

Erilaisiin tyyleihin perehtyminen on tuonut omaan pelimannisoittooni uusia elementtejä, mutta lisäksi olen ymmärtänyt, että tätä musiikkia voi lähestyä aiempaa laajemmasta perspektiivistä. Pokelan tapa soittaa Hienohelmaan variaatiota variaation päälle on saanut minut pohtimaan melodian hahmottamisen merkitystä pelimannimusiikissa eri tavalla kuin ennen. Soittaessani arkistotallenteen kanssa olen havainnut musiikissa eräänlaisen yhteyden pienkanteleiden yhdysasentoiseen soittotraditioon, joka perustuu yhden teeman jatkuvaan muuntelemiseen ja jossa melodialinjaa on vaikea eritellä (Laitinen: 2003a, 158). Ehkäpä Arvi Pokelakaan ei ajatellut melodiaa "kiveen hakattuna" kanteletta soittaessaan? 
Tämän pohdinnan seurauksena oivalsin, että pienkantelemusiikille ominainen alituisen muuntelun estetiikka voi olla läsnä myös pelimannimusiikissa.

Olemassa olevien tallenteiden määrä suhteessa tikkusoiton laajuuteen 1900-luvun alkupuolella on häviävän pieni, mutta tällainenkin otos voi olla merkittävä eri tyylien kirjon ymmärtämiselle. Tässä artikkelissa kymmenen soittajan joukosta oli valittu lähemmän tarkastelun kohteeksi kolme pelimannia, ja jo heidän soittotyyleihinsä ja -tekniikkoihinsa perehtyminen muutti käsitystäni tikkusoiton moni-ilmeisyydestä ratkaisevasti. Tältä pohjalta on mahdollista kuvitella, millainen kirjo eri tyylejä on ollut olemassa sata vuotta sitten, kun elettiin tikkusoiton kukoistuskautta. Tulevaisuudessa arkistot toivottavasti tarjoavat lisää valaistusta aiheeseen, sillä on hyvin mahdollista, ettei niiden kaikkia tikkusoittoa sisältäviä nauhoja ole vielä löydetty. Aion jatkaa soivaa tutkimusta tikkusoitosta sekä arkistoista lisämateriaalia etsien että nykyisiä tallenteitani hyödyntäen. Kiinnostava tikkusoiton tyylipiirre on esimerkiksi sointuvetäisy, sillä useimmat soittajat eivät käyttäneet sitä säännönmukaisesti kaikissa heiltä taltioiduissa kappaleissa. Soittotyyleissä riittää tutkittavaa, minkä lisäksi olisi hyödyllistä jatkaa myös Hannu Sahan (1996: 169-178) työtä tikkusoiton historian selvittämiseksi. Lisätietoa tarvittaisiin muun muassa tikkusoiton synnystä ja levinneisyydestä.

Pelimannimusiikin opetteleminen arkistotallenteilta on hyvin erilaista kuin sen oppiminen suoraan eläviltä pelimanneilta yhdessä musisoiden. Jälkimmäisestä itselläni on runsaasti kokemusta niin sanotun Perhonjokilaakson kanteleensoittotyylin parissa, sillä olen vuosien varrella päässyt soittamaan monien tätä soittotapaa edustavien pelimannien kanssa. Yhteiset soittohetket ovat olleet voimakkaita elämyksiä. Soittamisen ohella pelimannien kertomien tarinoiden ja elämänfilosofisten pohdintojen kuunteleminen on ollut merkityksellistä, sillä ne ovat auttaneet ymmärtämään syvemmin myös musiikin estetiikkaa ja historiallista ulottuvuutta. Pelimannien rinnalla musisoidessani olen päässyt osaksi heidän perinnettään ja sitä kautta löytänyt paikkani pelimannimusiikin traditiossa.

Pelimannimusiikin tyylejä opiskeleva muusikko kohtaa useita haasteita, kun verrataan arkistonauhoilta oppimista musisointiin elävän, historiallista perinnettä edustavan pelimannin kanssa. Koska arkistonauhoille soitettu musiikki itsessään sisältää runsaasti informaatiota, harjaantunut soittaja kykenee kuuntelemalla ja kokeilemalla saamaan siitä paljon irti, etenkin jos nauhoitteet ovat äänenlaadultaan kohtuullisia. Kappaleiden soittoteknisten yksityiskohtien hah- 
mottaminen pelkän tallenteen perusteella voi toki olla haasteellista, mutta ongelmallisimmaksi asiaksi omalla kohdallani nousi vuorovaikutuksen puuttuminen. Kun kohtaamiset elävässä elämässä olivat mahdottomia, perinne tuntui lähtökohtaisesti jopa odottamattomassa määrin vieraalta. Tämä perinnetyylien tutkimusprosessin alkuvaiheessa ilmennyt vierauden tunne oli yllättävä siksi, että tikkusoitto on itselleni kaikista kanteleensoittotekniikoista läheisin ja pelimannimusiikin estetiikkakin tuttua.

Perinnettä ovat auttaneet tuomaan lähemmäs kuvitteelliset kenttämatkat ja vuoropuhelut (Laitinen 2003b: 314). Olenkin pohtinut, millaisia asioita olisin halunnut soittajilta kysellä, jos vuoropuhelu olisi ollut mahdollista. Olen tullut siihen tulokseen, että kaipuu kohtaamiseen on ollut vahvempi kuin tarve saada selville teknisiä yksityiskohtia tai syitä musiikillisiin ratkaisuihin: olisin halunnut oppia tuntemaan nämä nauhojen välityksellä tutuiksi käyneet pelimannit soittajina ja ihmisinä. En tiedä, kuinka paljon keskustelut olisivat käsitelleet musiikkia. Väitöstutkimusta tehdessään Hannu Saha musisoi vuosien ajan perhonjokilaaksolaisten kantelepelimannien kanssa. Hänen mukaansa (1996: 111) sanallinen kommunikaatio oli lopulta vain apuväline, sillä musisoiden saavutettu vuorovaikutus oli niin ainutkertaista. Omien kokemusteni perusteella voin olla tästä samaa mieltä.

Tikkusoittoperinteeseen liittynyt vierauden tunne on vuorovaikutuksen puuttumisen ohella sidoksissa myös pelimannimusiikin funktion muutokseen. Kun tikkusoitto oli yleinen kanteleensoittotapa, se oli käytössä muun muassa tansseissa ja iltamissa. Myöhemmin kansanmusiikista on tullut estraditaidetta, ja sitä esitetään usein asetelmassa, jossa muusikot soittavat lavalla ja yleisö kuuntelee hiljaa paikallaan istuen. Olenkin pohtinut, millaisiin soittotilanteisiin arkistotallenteilta peräisin olevan ohjelmiston voisi tänä päivänä liittää, jotta musiikilla olisi samankaltainen käyttötarkoitus kuin ennen. Yhtenä vastauksena näen tanssisoiton ja siksi olen suunnitellut produktiota, jossa tikkusoittajista koostuva kanteleyhtye soittaisi pelimannitanssit.

Tutkimusmatkani tikkusoittoperinteeseen on yksi osoitus siitä, että arkistot ovat erittäin tärkeä tiedon ja inspiraation lähde tämän päivän kansanmuusikolle. Ongelmana ei ole tiedon saatavuus, vaan sen äärelle etsiytyminen ja ylipäätään perinteestä kiinnostuminen. Nuorten kansanmuusikoiden kohtaamiset elävien pelimannien kanssa ja niiden mahdollistamat, vuorovaikutuksen välityksellä 
löytyvät elämykset ovat käyneet valitettavan harvinaisiksi. Samalla maailma on tulvillaan klikkauksen päässä olevaa kiinnostavaa musiikkia. Millaisin keinoin kansanmusiikin koulutus kykenee vastaamaan tähän haasteeseen? Jatkossa olisi kiinnostavaa syventyä lisää tähänkin aihepiiriin.

Kun seikkailee avoimin mielin ja korvin, arkistonauhojen parissa avautuu mielikuvituksellinen ja rikas maailma, jonka höysteenä on myös luovaa hulluutta. Historialliset ilmiöt muuttuvat kuulokuvan avulla eläviksi, ja joka askeleella, nauha nauhalta niiden parissa työskentelevä muusikko ymmärtää enemmän kansanmusiikin syvistä juurista. Hiljalleen kansanmusiikin eri aikakaudet, tyylit ja soittajat tulevat lähemmäs: pelimannien äänenpainot heidän kertoessaan tarinaa, heidän tapansa fraseerata, heidän omat persoonalliset maneerinsa. Tulee halu kuunnella ja oppia lisää, saada arkistot soimaan osana tämän päivän musiikkia. Syvällinen perehtyminen arkistoihin ja tikkusoittoperinteeseen on saanut aikaan ymmärryksen siitä, että olen omana luovana itsenäni osa perinteen jatkumoa.

\section{LÄHDELUETTELO}

\section{Arkistolähteet}

Kansanmusiikki-instituutti, Kaustinen:

КIÄ 1116 Albin Saari. Kauhava. Nauhoittajasta ei tietoa.

Kansanperinteen arkisto, Yhteiskunta- ja kulttuuritieteiden yksikkö, Tampereen yliopisto:

Kper A-K o054. Alfred Backman. Keuruu 1954. Nauhoittaja: Erkki Ala-Könni. (Kuunneltavissa osoitteessa http:/ /www.etnomusikologia.fi/p/av2018.html)

Kper A-K 0781. Kalle Hakasalo. Saarijärvi 1963. Nauhoittaja: Erkki Ala-Könni.

Kper A-K 1595. Kannonkosken pelimannit. Kaustinen 1969. Nauhoittaja: Erkki Ala-Könni.

Kper A-K 1418. Salomo Korhonen 1968. Nauhoittaja: Erkki Ala-Könni.

Kper A-K 4510. Aarne Moisio 1977. Nauhoittaja: Erkki Ala-Könni. (Kuunneltavissa osoitteessa

http:/ /www.etnomusikologia.fi/p/av2018.html)

Kper A-K ooo46. Liinus Simpsiö 1954. Nauhoittaja: Erkki Ala-Könni. 
Saarijärven museo:

Kasettinauha 122:32. Eino Manninen. Saarijärvi 15.3.1979. Nauhoittaja: Arvi Pokela.

Kasettinauha 91:10. Veikko Manninen. Saarijärvi 15·3.1979. Nauhoittaja: Arvi Pokela.

The Library of Congress, Archive of Folk Culture, Washington DC:

AFS 3274-3275; 3298B. Matti Perala. Mountain Iron, Minnesota, Yhdysvallat 1937. Nauhoittaja:

Sidney Robertson.

\section{Äänitejulkaisut}

Aarnion Sisarukset (1993) Hämeen polkka. Kansanmusiikki-instituutti KICD 28.

Pokela, Arvi (1991) Saarijärven kantele. Kansanmusiikki-instituutti Kı Ä 780. (Kuunneltavissa osoitteessa http:/ /www.etnomusikologia.fi/p/av2018.html)

Rankan polkka (2012) Useita soittajia. Kanteleliitto Kanli-CD o02.

\section{Videoklipit}

Ote Hienohelma ja hyppivä puuhevonen -konsertista 26.9.2014 (Katseltavissa osoitteessa http:/ /www.etnomusikologia.fi/p/av2018.html)

Videoklippi 1: Pokelan soitteeseen pohjautuva Heramäen pukki Pauliina Syrjälän esittämänä.

Videoklippi 2: Backmanin soitteeseen pohjautuva Hienohelma Pauliina Syrjälän ja Maija Kauhasen esittämänä.

Videoklippi 3: Yhdeksänhenkinen kanteleyhtye esittää Moision soitteeseen pohjautuvan Hienohelman.

\section{Haastattelut}

Kontio, Sinikka (h2018) Helsinki 12.1.2018. Haastattelija: Pauliina Syrjälä. Haastattelunauha tutkijan hallussa.

Nieminen, Rauno (h2014) Ikaalinen 31.8.2014. Haastattelija: Pauliina Syrjälä. Haastattelunauha tutkijan hallussa. 
Nieminen, Rauno (h2018) sähköpostihaastattelu. Haastattelija: Pauliina Syrjälä. Kysymyslista lähetetty 17.1.2018, vastaus saatu 17.1.2018. Haastattelumateriaali tutkijan hallussa.

\section{Kirjallisuus}

Ala-Könni, Erkki (1986[1963]) "Saarijärven kantele". Kansanmusiikki, tutkielmia neljältä vuosikymmeneltä. Erkki Ala-Könni. Kaustinen: Kansanmusiikki-instituutti, 31-38.

Asplund, Anneli (2006) "Kansanmusiikin paluu". Suomen musiikin historia: Kansanmusiikki. Toim. Anneli Asplund, Heikki Laitinen, Timo Leisiö, Hannu Saha \& Simo Westerholm. Porvoo: WSOY, 506-523.

Dahlblom, Kari (2011) Keski-Suomen kantele. Äänekoski: Kari ja Tuula Dahlblom.

Dahlblom, Kari \& Nieminen, Rauno (2012) "Keski-Suomen kantele". Kantele 4/2012, 24-31.

Hakala, Joyce E. (1997) Memento of Finland - A Musical Legacy. St. Paul: Pikebone Music.

Haynes, Bruce (2007) The End of Early Music: A Period Performer's History of Music for the TwentyFirst Century. Oxford: Oxford University Press.

Hood, Mantle (1971) The Ethnomusicologist. Los Angeles: Institute of Ethnomusicology, University of California.

Karttunen, Assi (2013) "Retorinen l'obscurité - historiallinen tiedostaminen muusikon työprosessissa". Musiikki 3-4/2013, 142-162.

Kurkela, Vesa (1991) "Etnomusikologian historiattomuus ja nykyajan haasteet". Kansanmusiikin tutkimus, metodologian opas. Toim. Pirkko Moisala. Helsinki: vapk-kustannus, 86-101.

Laitinen, Heikki (2003a) Iski sieluihin salama. Kirjoituksia musiikista. Helsinki: Suomalaisen Kirjallisuuden Seura.

Laitinen, Heikki (2003b) Matkoja musiikkiin 180o-luvun Suomessa. Tampere: Tampereen yliopisto. Lindblad, Kurt (1992) “Arvi Pokela”. Mestaripelimannit. Toim. Ilkka Kolehmainen. Kaustinen: Kansanmusiikki-instituutti, 149-152.

Lomax, Alan (1968) Folk Song Style and Culture. New Brunswick, New Jersey: Transaction Books. Moisala, Pirkko (1993) "Soittotyylin analyysi". Musiikin suunta 3/1993, 7-16.

Nettl, Bruno (1964) Theory and Method in Ethnomusicology. New York: The Free Press of Glencoe. Ong, Walter J. (2002 [1982]) Orality and Literacy. The Technologizing of the World. New York: Routledge.

Saha, Hannu (1996) Kansanmusiikin tyyli ja muuntelu. Kaustinen: Kansanmusiikki-instituutti. Saha, Hannu (2006) "Kantele". Suomen musiikin historia: Kansanmusiikki. Toim. Anneli Asplund, Heikki Laitinen, Timo Leisiö, Hannu Saha \& Simo Westerholm. Porvoo: wsoy, 399-418. 
Saha, Hannu (2010) "Taiteellisen tutkimuksen haasteet Sibelius-Akatemiassa". Musiikki 3-4/2010, 84-96.

Talvitie-Kella, Tuuli (2010) Hääpolskasta haitarijatsiin. 190o-luvun alun tanssimusiikkikulttuuri eteläpohjalaisten tanssisoittajien kertomana, kokemana ja soittamana. Tampere: Suomen Etnomusikologinen Seura.

Tenhunen, Anna-Liisa (2010) "Kanteleen suuri nousu". Kantele. Toim. Risto Blomster. Helsinki: Suomalaisen Kirjallisuuden Seura, 171-307.

Varto, Juha (2017) Taiteellinen tutkimus. Mitä se on? Kuka sitä tekee? Miksi? Helsinki: Aalto ARTs Books. 